\title{
Commentary
}

The report describes a patient with hypertensive hydrocephalus caused by the $\mathrm{H} 2 \mathrm{~N} 3$ virus, which is an extremely rare condition. ${ }^{[1]}$ Identification of influenza virus type $\mathrm{A}$ in cerebrospinal fluid using polymerase chain reaction method confirmed central nervous system (CNS) involvement. Cerebrospinal fluid biochemistry excluded the presence of meningitis or encephalitis. There was also no associated aqueduct stenosis. The surgically treated coincidental vestibular schwannoma has not been shown to be associated with the hydrocephalus or the neurological symptoms described.

Several pathological observations of viral infections of the CNS resulting in hydrocephalus, such as perivascular inflammatory response, subependymal gliosis and neovascularization, necrosis of ependymal cells and aqueductal stenosis have been described in experimental animals. These findings were associated with viral replication. ${ }^{[2]}$ Viruses that have been reported to produce hydrocephalus include parainfluenza type $1^{[2]}$ and $2,{ }^{[3]}$ mumps, ${ }^{[4]}$ influenza $A,{ }^{[5]}$ type 12 adenovirus, ${ }^{[6]}$ reovirus type $1,{ }^{[7]}$ and polyomavirus. ${ }^{[8]}$ Mims have analyzed the intracerebral toxicity for mice of standard and neuroadapted strains of influenza A virus. $\mathrm{He}$ described the destruction of the ependymal lining of the ventricles, and a severe inflammatory response originating in the ventricles, but also affecting the ependymal cells covering the choroid plexuses, which eventually produces the frankly hydrocephalic condition seen in mice dying after 6-7 days. ${ }^{[5]}$ Subsequent to the animal studies a number of children have been reported with hydrocephalus and aqueductal stenosis 5 weeks to 4 years after mumps virus infection. ${ }^{[9]}$

Although this report is only the second case described of H3N2 type A influenza virus-related hydrocephalus, clinicians should be aware that influenza virus is a potential cause of brain damage and hydrocephalus. Neuroimaging should be performed early in the presence of signs and symptoms of intracranial hypertension.

\section{Amauri Dalla-Corte}

Post-Graduate Program in Medical Sciences, Universidade Federal do Rio Grande do Sul, Porto Alegre, Brazil
Address for correspondence: Dr. Amauri Dalla-Corte, Universidade Federal do Rio Grande do Sul, Rua Ramiro Barcelos 2350, Porto Alegre, RS 90035-903, Brazil. E-mail: dalacorte@gmail.com

\section{REFERENCES}

1. Nemir J, Domazet I, Brgic K, Kovac N, Mrak G. Hydrocephalus caused by $\mathrm{H} 3 \mathrm{~N} 2$ type A influenza virus or cerebellopontine angle schwannoma? J Neursci Rural Pract 2017;8:694-5.

2. Friedman HM, Gilden DH, Lief FS, Rorke LB, Santoli D, Koprowski H, et al. Hydrocephalus produced by the 6/94 virus; A parainfluenza type 1 isolate from multiple sclerosis brain tissue. Arch Neurol 1975;32:408-13.

3. Johnson RT, Johnson KP. Hydrocephalus as a sequela of experimental myxovirus infections. Exp Mol Pathol 1969;10:68-80.

4. Johnson RT, Johnson KP. Hydrocephalus following viral infection: The pathology of aqueductal stenosis developing after experimental mumps virus infection. J Neuropathol Exp Neurol 1968;27:591-606.

5. Mims CA. An analysis of the toxicity for mice of influenza virus. I. Intracerebral toxicity. Br J Exp Pathol 1960;41:586-92.

6. Huebner RJ, Rowe WP, Lane WT. Oncogenic effects in hamsters of human adenovirus types 12 and 18. Proc Natl Acad Sci U S A 1962;48:2051-8.

7. Margolis G, Kilham L. Hydrocephalus in hamsters, ferrets, rats, and mice following inoculations with reovirus type I. II Pathologic studies. Lab Invest 1969;21:189-98.

8. Holtz A, Borman G, Li CP. Hydrocephalus in mice infected with polyoma virus. Proc Soc Exp Biol Med 1966;121:1196-200.

9. Johnson RT. Hydrocephalus and viral infections. Dev Med Child Neurol 1975;17:807-16.

This is an open access article distributed under the terms of the Creative Commons Attribution-NonCommercial-ShareAlike 3.0 License, which allows others to remix, tweak, and build upon the work non-commercially, as long as the author is credited and the new creations are licensed under the identical terms.

\begin{tabular}{|l|l}
\hline \multicolumn{2}{c}{ Access this article online } \\
\hline Quick Response Code: & \multicolumn{1}{|c|}{ Website: } \\
& www.ruralneuropractice.com \\
& \\
\end{tabular}

How to cite this article: Dalla-Corte A. Commentary. J Neurosci Rural Pract 2017;8:694. 